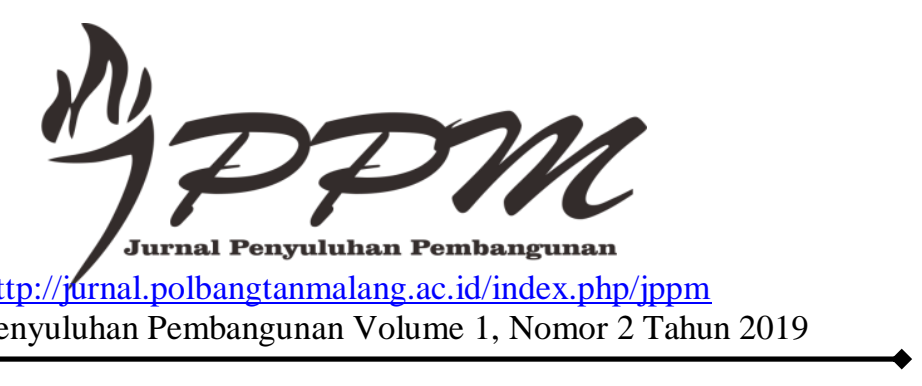

Jurnal Penyuluhan Pembangunan Volume 1, Nomor 2 Tahun 2019

\title{
KETERAMPILAN PETERNAK TENTANG PEMBUATAN PUPUK ORGANIK CAIR DARI KOTORAN KAMBING DI DESA WONOREJO
}

\section{THE FARMERS' SKILLS OF MAKING LIQUID ORGANIC FERTILIZER FROM GOAT MANURE IN WONOREJO VILLAGE}

\author{
Ganang Trisno Priyambodo ${ }^{1}$, Kartika Budi Utami $^{2}$, Abdul Muksid $^{2}$ \\ ${ }^{1,2}$ Program Studi Penyuluhan Peternakan dan Kesejahteraan Hewan, Polbangtan Malang; \\ Jl. Dr. Cipto 144 a Bedali Lawang 65200, (0341) 427771/2 \\ e-mail: ${ }^{1}$ ganangtrisno5@gmail.com,${ }^{2}$ kartika.b.utami@ polbangtan.ac.id
}

\begin{abstract}
Abstrak
Tujuan penelitian yaitu mendeskripsikan keterampilan peternak tentang pembuatan pupuk organik cair dari kotoran kambing. Materi penelitian yaitu 25 orang peternak yang ditentukan secara purposive sampling. Metode penelitian yang digunakan yaitu studi kasus. Penelitian telah dilakukan pada bulan Maret-Juni 2018. Keterampilan peternak meliputi keterampilan dalam prosedur pembutan pupuk organik cair pada tahap persiapan, pencampuran dan pengakhiran. Data tentang keterampilan peternak diperoleh menggunakan kuesioner melalui observasi. Kualitas pupuk organik cair meliputi kualitas fisik dan kandungan unsur hara. Kualitas fisik meliputi bau, warna, konsistensi dan tekstur. Kandungan unsur hara meliputi C-Organik, $p H, N, P$ dan K. Kualitas fisik POC diketahui dengan uji organoleptik sedangkan kandungan unsur hara dilakukan uji laboratorium. Data dianalisa secara deskriptif.

Hasil penelitian menunjukkan bahwa secara umum tingkat keterampilan peternak tentang pembuatan pupuk organik cair dari feses kambing pada kategori terampil. Pada tahap persiapan sejumlah 13 orang atau 52\% peternak dengan kategori terampil, pada tahap pencampuran sejumlah 15 orang atau $60 \%$ peternak dengan kategori cukup terampil dan pada tahap pengakhiran sejumlah 21 orang atau 84\% peternak pada kategori sangat terampil.
\end{abstract}

Kata kunci-Keterampilan, pupuk organik cair, feses kambing.

\section{Abstract}

The purpose of the research is to describe the farmers' skills about making liquid organic fertilizer from goat manure. The research material was 25 farmers who were determined by purposive sampling. The research method used is a case study. Research has been carried out in March-June 2018. The skills of the breeders include skills in the procedure for making liquid organic fertilizer at the stage of preparation, mixing and ending. Data on breeders' skills were obtained using a questionnaire through observation. The quality of liquid organic fertilizer includes physical quality and nutrient content. Physical quality includes smell, color, consistency and texture. Nutrient content includes C-Organic, $p H, N, P$ and $K$. The physical quality of $P O C$ is known by organoleptic test while the nutrient content is carried out laboratory tests. Data is 
analyzed descriptively. The results of the study show that in general the skill level of the farmer about making liquid organic fertilizer from goat faeces in the skilled category. Atthe preparation stage there were 13 people or $52 \%$ of farmers with the skill category, at the mixing stage there were 15 people or $60 \%$ of farmers with quite skilled categories and at the termination stage there were 21 people or $84 \%$ of farmers in the highly skilled category.

Keywords - Skills, liquid organic fertilizer, goat feces.

\section{PENDAHULUAN}

Pertanian organik sedang berkembang dan memerlukan peningkatan pasokan pupuk organik diantaranya yang berpotensi dikembangkan di Indonesia adalah pupuk organik padat atau feses yang bisa dimanfaatkan sebagai pupuk organik cair. Oleh karenanya jika peternak bisa mengelola dan memanfaatkan limbah dari feses kambing maka akan mendapatkan input dan keuntungan ganda dari peternakannya.Segala hal yang ada di sekitar peternakan kambing mempunyai nilai ekonomi, tidak terkecuali adalah kotoran ternak. Bagi pemilik/pemelihara peternakan produksi kotoran akan melimpah baik itu kotoran dalam bentuk cair/ urine maupun kotoran keras. Semua kotoran tersebut tidak ada yang terbuang akan tetapi dijadikan pupuk organik sehingga akan dapat menjadi tambahan pendapatan dalam mengelola peternakan. Untuk mengatasi masalah ini, program pengolahan limbah semakin digalakkan, di antaranya dengan mengolahnya menjadi pupuk dan pakan ternak. Cara ini dapat mengurangi dampak negatif sampah sekaligus memberikan profit dan menciptakan lapangan pekerjaan melalui usaha pengolahan limbah organik.

Konsep peternakan yang dijalankan seperti ini, peternak akan mendapatkan keuntungan yang lebih besar dengan di dukung faktor usaha lainnya. Selain mendapatkan laba dari ternak yang dipelihara, juga akan mendapatkan laba dari kotoran ternak melalui pupuk organik. Cara menjalankan masing - masing usaha secara terintegrasi akan lebih komplek seandainya sekalian dijalankan dengan melakukan kegiatan pertanian. Mulai dari cara menernakkan kambing, mengolah kotoran ternak menjadi pupuk organik, hingga menanam sayuran organik (Subhan et.al, 2009).

Desa Wonorejo merupakan wilayah yang ada di Kecamatan Lawang Kabupaten Malang, luas kecamatan Lawang secara keseluruhan adalah adalah sekitar $68.23 \mathrm{~km}^{2}$ atau sekitar 2,29 \% dari total luas kabupaten Malang. Desa Wonorejo terletak di ketinggian antara 485-560 mdpl dengan curah hujan sekitar $349 \mathrm{~mm} / \mathrm{tahun}$. Sebagian besa penduduknya bermata pencahariaan sebagai petani dan peternak, dengan jumlah populasi ternak Kambing yang jumlahnya cukup banyak yaitu 407 ekor. Menurut Widowati dkk. 2005, Tiap satu ekor kambing akan mengasilkan $\pm 4 \mathrm{~kg}$ feses per harinya ,untuk perhitungan jumlah produksi feses kambing dalam satu desa yaitu $407 \mathrm{x} 4 \mathrm{~kg}=1628 \mathrm{~kg}$. Dimana dengan jumlah produksi feses kambing yang begitu banyak sangat berpotensi untuk diterapkan teknologi pupuk organik cair . Di desa Wonorejo terdiri dari 3 kelompok tani antara lain Karya Makmur 1, Karya Makmur 2, dan Arjuno.Kelompok Tani Karya Makmur 1 dan Arjuna sudah mampu memproduksi Pupuk Organik cair, sedangkan Karya Makmur 2 belum dapat membuat pupuk organik cair tetapi kegiatan penyuluhan sudah sering dilakukan.Berdasarkan hasil identifikasi lapangan rata-rata feses kambing belum di manfaatkan secara optimal dan peternak belum dapat membuat pupuk organik. Untuk itu dalam penelitian ini penulis mengambil judul "Rancangan Penyuluhan Tentang Cara Pembuatan Pupuk Organik Cair Dari Limbah Kotoran Kambing" maka penulis merasa tertarik mengetahui tanggapan yang berupa perubahan keterampilan, yang dimiliki oleh peternak terhadap penggunaan limbah kotoran ternak sebagai pupuk organik cair, di Kecamatan Lawang Kabupaten Malang, agar peternak mau menggunakan pupuk organik cair sebagai pupuk tanaman maka kami akan melakukan penyuluhan feses kambing ini bagi masyarakat peternak. 


\section{METODE PENELITIAN}

\section{Lokasi dan waktu}

Lokasi penelitian dilaksanakan di Kelompok Tani Desa Wonorejo Kecamatan Lawang Kabupaten Malang Provinsi Jawa Timur. Penelitian telah dilakukan pada bulan Maret -Juni 2018.

\section{Materi penelitian}

Materi penelitian yaitu 25 orang anggota kelompok tani karya makmur 2 di Desa Wonorejo. Sampel ditentukan secara sengaja (purposive sampling) dengan kriteria yang telah ditetapkan yaitu: (a) Setiap responden memiliki 2-5 ekor kambing; (b) Kelompok tani karya makmur 2 termasuk kelompok yang sangat aktif dan memiliki populasi kambing terbanyak diantara 3 kelompok tani lain yang ada di desa Wonorejo.

Bahan yang digunakan dalam membuat POC feces kambing yaitu feses kambing $5 \mathrm{~kg}$, air 10 liter, EM4 $100 \mathrm{cc}$ air 1 liter air, Gula Pasir $250 \mathrm{~g}$ Drum plastik, timbangan, ember. Pembuatan POC berdasarkan pada hasil penelitian yang dilakukan oleh Adhis dkk (2017).

\section{Pengukuran keterampilan peternak}

Variable pengukuran ditentukan oleh peneliti dan dibandingkan dengan kenyataan yang ada dilapangan. Setelah itu menjabarkan menggunakan metode deskriptif kualitatif. Dalam hal ini pengukuran menggunakan Rating Scale. Adapun kategori penilaian keterampilan antara lain: (a) Sangat tidak terampil; (b) Tidak terampil; (c) Cukup terampil; (d) Terampil; (e) Sangat terampil.

Keterampilan peternak meliputi penilaian keterampilan pada 3 tahapan prosedur antara lain: (1) Tahap Persiapan; (2) Tahap Pecampuran; (3) Tahap Pengakhiran.

Diagram tahapan proses pembuatan POC faeses kambing disajikan pada Gambar 1.

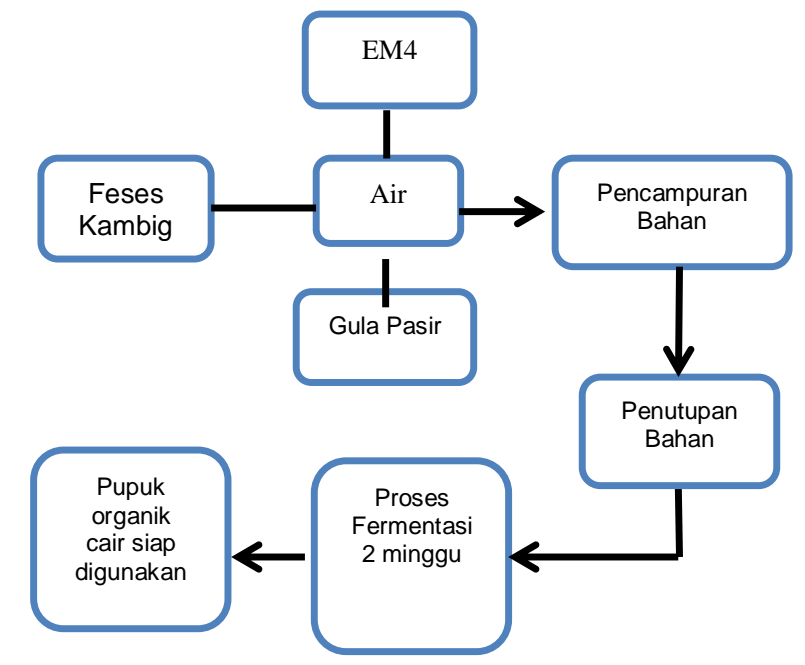

Gambar 1. Tahapan prosedur pembuatan POC feces kambing.

Langkah Kerja :

\section{a. Tahap Persiapan}

(a) Mengidentifikasikan jenis alat; (b) Mempersiapkan alat; (c) Mempersiapkan feses; (d) Memisahkan sisa pakan (rumput) dengan feses kambing; (e) Menimbang feses kambing sesuai takaran; (f) Mempersiapkan EM4; (g) Menimbang EM4; (h) Mempersiapkan gula pasir; (i) Menimbang gula pasir; (j) Mempersiapkan air; (k) Menimbang air.

\section{a. Tahap Pencampuran}

(a) Memasukkan feses; (b) Menuangkan EM4; (c) Menuangkan larutan gula pasir. 


\section{c. Tahap Pengakhiran}

(a) Menutup drum secara baik; (b) Mendorong penutup drum dengan rapat; (c) Menyimpan drum.

\section{Kualitas POC feces kambing}

Kualitas fisik dikaji secara organoleptik seperti disajikan pada Tabel 1.

Tabel 1. Indikator kualitas fisik POC feces kambing

\begin{tabular}{ccc}
\hline No & Parameter & Hasil uji organoleptik \\
\hline 1 & Bau & Tidak berbau \\
2 & Warna & Coklat \\
3 & Konsistensi & Encer \\
4 & Tekstur & Kasar \\
\hline
\end{tabular}

sedangkan kandungan unsur hara POC dikaji berdasarkan Permentan no 70 tahun 2011, disajikan pada Tabel 2.

Tabel 2. Persyaratan unsur hara pupuk organik cair

\begin{tabular}{cccc}
\hline No & Parameter & Satuan & Standar Mutu \\
\hline 1 & $\mathrm{pH}$ & & $4-9$ \\
2 & C-Organik & $\%$ & Min 6 \\
4 & $\mathrm{~N}$ & $\%$ & $3-6$ \\
5 & $\mathrm{P}$ & $\%$ & $3-6$ \\
6 & $\mathrm{~K}$ & $\%$ & $3-6$ \\
\hline
\end{tabular}

Sumber: Permentan No 70, 2011.

Uji kualitas unsur hara pupuk organik cair dilakukan di Laboratorium BALITKABI Kabupaten Malang.

\section{HASIL DAN PEMBAHASAN}

\section{Keterampilan peternak dalam melaksanakan prosedur pembuatan POC dari feces kambing}

Rekapitulasi tentang keterampilan peternak dalam melaksanakan prosedur pembuatan POC disajikan pada Tabel 3.

Tabel 3. Hasil pengukuran tingkat keterampilan

\begin{tabular}{ccccc}
\hline No & Indikator & Kategori & Jumlah Orang & Persentase \\
\hline $\mathbf{1}$ & Tahap Persiapan & Terampil & 13 & 52 \\
$\mathbf{2}$ & Tahap Pecampuran & Cukup Terampil & 15 & 60 \\
$\mathbf{3}$ & Tahap Pengakhiran & Sangat Terampil & 21 & 84 \\
\hline
\end{tabular}

Sumber : Data primer diolah, 2018.

Tabel 3 menunjukkan bahwa pada tahap persiapan, peternak termasuk pada kategori terampil dengan jumlah 13 orang atau 52\%. Pada tahap pencampuran, sejumlah 15 orang atau $60 \%$ peternak termasuk kategori cukup terampil, sedangkan pada tahap pengakhiran sejumlah 21 orang atau $84 \%$ peternak termasuk kategori sangat terampil.

\section{a. Tahap Persiapan}

Keterampilan peternak pada tahap persiapan termasuk kategori terampil, seperti disajikan pada Gambar 2. 


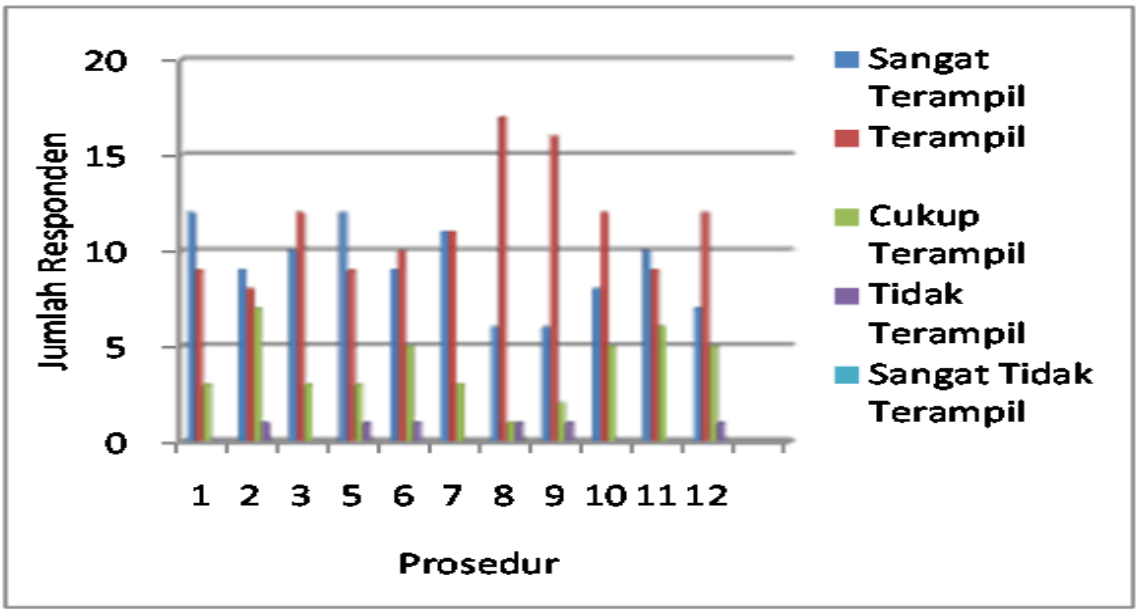

Keterangan:

Gambar 2. Keterampilan peternak pada tahap persiapan

Prosedur 1 : Mengidentifikasikan jenis alat

Prosedur 2 : Mempersiapkan alat

Prosedur 3 : Mempersiapkan feses

Prosedur 5 : Memisahkan sisa pakan (rumput) dengan feses kambing

Prosedur 6 : Menimbang feses kambing sesuai takaran

Prosedur 7 : Mempersiapkan EM4

Prosedur 8 : Menimbang EM4

Prosedur 9 : Mempersiapkan gula pasir

Prosedur 10 : Menimbang gula pasir

Prosedur 11 : Mempersiapkan air

Prosedur 12 : Menimbang air

Gambar 3 menunjukkan bahwa peternak terampil dalam melaksanakan prosedur 8 dan prosedur 9, yaitu pada prosedur menimbang EM4 dan mempersiapkan gula pasir.Kedua bahan tersebut harus dengan takaran yang tepat karena akan mempengaruhi efektifitas proses fermentasi. Effective microorgnisme atau EM4 merupakan suatu cairan berwarna kecoklatan dan beraroma manis asam segar yang didalamnya berisi campuran beberapa mikroorganisme hidup, sedangkan gula pasir digunakan sebagai sumber makanan mikroorganisme pada proses pembuatan pupuk organik cair dari feses kambing.

\section{b. Tahap Pencampuran}

Keterampilan peternak pada tahap pencampuran termasuk pada kategori cukup terampil, seperti disajikan pada Gambar 3.

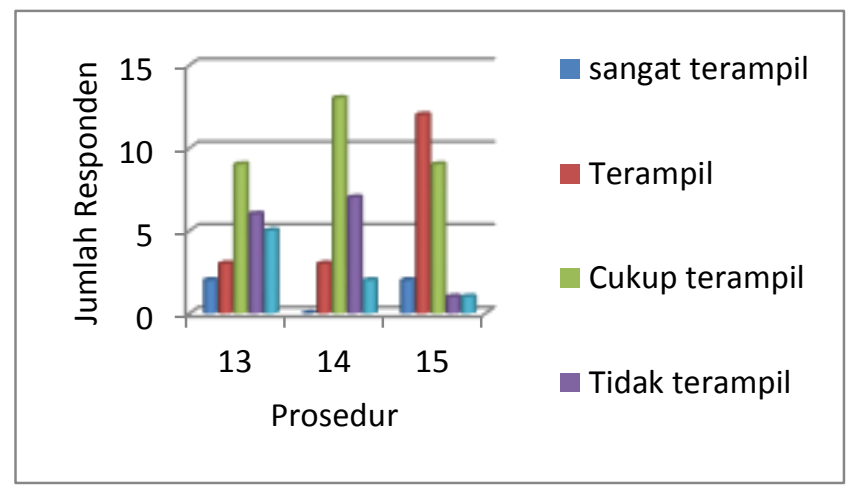

Keterangan :

Gambar 3. Keterampilan peternak pada tahap pencampuran.

Prosedur 13 : Memasukkan feses 
Prosedur 14 : Menuangkan EM4

Prosedur 15 : Menuangkanlarutan gula pasir

Gambar 4 menunjukkan bahwa peternak cukup terampil dalam melaksanakan prosedur 14, yaitu sejumlah 13 orang peternak dapat memasukkan EM4 ke dalam drum sesuai dengan prosedur yang dianjurkan. Semua bahan harus tercampur dengan tepat, jika dalam proses memasukkan EM4 tidak tepat atau ada yang tumpah, maka akan mengurangi jumlah mikroorganisme yang berperan penting dalam proses pembuatan POC. Mikroorganisme berperan dalam proses fermentasi yang membutuhkan waktu selama 14 hari pemeraman.

Tahap pecampuran merupakan tahap yang harus diperhatikan apabila pencampuran yang dilakukan tidak homogen maka proses fermentasi POC berjalan tidak efektif.

\section{c. Tahap pengakhiran}

Keterampilan peternak pada tahap pengakhiran termasuk pada kategori sangat terampil, seperti disajikan pada Gambar 4.

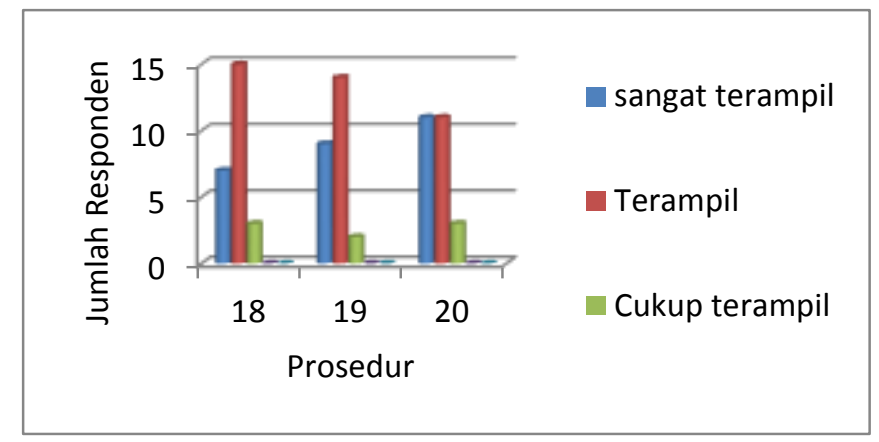

Keterangan :

Gambar 4. Keterampilan peternak pada tahap pengakhiran

Prosedur 18 : Menutup drum secara baik

Prosedur 19 : Mendorong penutup drum dengan rapat

Prosedur 20 : Menyimpan drum

Gambar 5 menunjukkan bahwa peternak sangat terampil dalam melaksanakan prosedur 18 dimana 15 orang peternak menutup drum secara baik. Menutup drum secara baik bertujuan agar tidak ada udara yang masuk di dalam drum. Apabila udara masuk terlalu lama pada drum akan menghambat kinerja mikroorganisme dalam proses fermentasi.

Prosedur pada tahap pengakhiran bertujuan untuk menciptakan kondisi anaerob agar proses fermentasi berjalan efektif. Hal ini ditentukan dari keterampilan peternak dalam menyimpan POC yang tersimpan di dalam drum. Drum harus ditutup dengan rapat kemudian ditempatkan pada ruangan yang kering dan teduh. Selama penyimpanan, drum tidak terkena sinar matahari secara langsung karena pupuk organik cair mengalami reaksi perombakan.

Hal ini sesuai dengan pendapat Latifah, dkk., (2012), Selama POC di simpan di tempat yang teduh, POC juga mengalami reaksi perombakan protein menjadi asam amino (aminasi) yang kemudian menjadi gas amoniak yang mengakibatkan munculnya aroma busuk. Gas amoniak ini aka bereaksi dengan air dan berubah menjadi ammonium (NH4-) yang mudah tersedia untuk mikroba dan tanaman (proses amonifikasi).

\section{Kualitas POC dari feses kambing yang dihasilkan oleh peternak}

Hasil uji fisik POC dari faeces kambing disajikan pada Tabel 13. 
Tabel 3. Hasil kualitas fisik pupuk organik cair

\begin{tabular}{ccc}
\hline Indikator & Hasil POC & Keterangan \\
\hline Bau & Tidak berbau & Sesuai \\
Warna & Warna kehitaman & Tidak sesuai \\
Kepekatan & Kepekatannya encer & Sesuai \\
Tekstur & Tekstur kasar & Sesuai \\
\hline
\end{tabular}

Tabel 3 menunjukkan bahwa terdapat perbedaan kualitas ciri-ciri fisik pupuk organik cair, yaitu pada indikator warna. Warna POC kehitaman dipengaruhi oleh bahan yang digunakan seperti feses yang digunakan sudah lama, sebaiknya faeces yang digunakan adalah faeces yang tidak terlalu lama (baru). Untuk hasil uji laboratorium disajikan pada Tabel 4.

Tabel 4. Hasil kualitas unsur hara pupuk organik cair

\begin{tabular}{cccccc}
\hline No & Parameter & Satuan & $\begin{array}{c}\text { Lab Balitkabi } \\
(\mathbf{2 0 1 8})\end{array}$ & $\begin{array}{c}\text { Adhis.dkk } \\
(\mathbf{2 0 1 7})\end{array}$ & $\begin{array}{c}\text { Permentan no 70 } \\
\text { tahun 2011 }\end{array}$ \\
\hline $\mathbf{1}$ & pH & & 9.6 & 7,15 & $4-8$ \\
$\mathbf{2}$ & C-Organik & $\%$ & 0.12 & 0,19 & $>4$ \\
$\mathbf{3}$ & N & $\%$ & - & 1,15 & $<2$ \\
$\mathbf{4}$ & $\mathrm{P}$ & $\%$ & 0.03 & 0,06 & $<2$ \\
$\mathbf{5}$ & $\mathrm{K}$ & $\%$ & 0.83 & 0,51 & $<2$ \\
\hline
\end{tabular}

Tabel 4 menunjukkan bahwa kandungan unsur hara POC dari hasil pemantapan materi dengan adhis., dkk (2017) tidak menunjukkan perbedaan, sedangkan jika dibandingkan dengan standar mutu Permentan nomor 70 tahun 2011 masih kurang sesuai.

Kisaran $\mathrm{pH}$ yang baik untuk pupuk organik yaitu sekitar 6,5-7,5 (netral) (Indriani, 2003). Sutanto (2006) menyatakan bahwa biasanya pH agak turun pada awal proses pengomposan karena aktivitas bakteri yang menghasilkan asam. Dengan munculnya mikroorganisme lain dari bahan didekomposisikan, maka $\mathrm{pH}$ akan naik setelah beberapa hari dan kemudian berada pada kondisi netral.

Rendahnya kandungan C-organik disebabkan oleh suhu dan kelembapan pada lingkungan sekitar yang tidak stabil.Suhu merupakan faktor yang penting bagi kehidupan bakteri, bakteri hidup dalam kondisi suhu yang sangat beragam. Bakteri yang menguntungkan umumnya hidup pada suhu optimum bagi pertumbuhan mahluk hidup lainnya yakni berkisar $18^{\circ} \mathrm{C}-40^{\circ} \mathrm{C}$. Suhu lingkungan yang terlalu tinggi dapat mengakibatkan denaturasi atau kerusakan protein dan komponen sel lainnya pada bakteri dekomposer sehingga dapat mengakibatkan kematian. Sedangkan suhu yang terlalu rendah dapat mengakibatkan mobilitas bakteri terhambat, dan jika terjadi kenaikan suhu secara ekstrim bakteri akan mati.Bakteri dapat berkembangbiak pada kondisi kelembaban yang relatif tinggi yakni RH mencapai $\pm 60 \%$, kelembaban tinggi berarti lingkungan cenderung berair, bakteri sangat menyukai pada kondisi lingkungan yang relatif berair Sutanto (2006).

Kandungan $\mathrm{N}$ yang kurang sesuai standar disebabkan oleh tidak dibukanya penutup wadah pembuatan poc pada saat proses fermentasi. Menurut Susetya (2015) pembukaan tempat pembuatan pupuk organik cair dalam waktu tertentu dimaksudkan agar pupuk cair mendapat sirkulasi udara. Hal ini sesuai dengan penelitian Wulandari (2015) bahwa faktor yang dapat menyebabkan penurunan kandungan nitrogen dikarenakan nitrogen dalam oksigen bentuk amonia sebagai hasil dari dekomposisi bahan organik yang lepas ke udara, kemudian tidak masuk secara merata pada tumpukan sehingga oksigen yang ada jumlahnya terbatas yang mengakibatkan amonia tidak dapat diubah ke dalam bentuk nitrat dan selanjutnya nitrogen hilang dalam bentuk gas $\mathrm{NH}_{3}$. Trivana et al. (2017) dalam adhis, dkk. (2017) menyatakan bahwa peningkatan kadar $\mathrm{N}$ 
kompos kotoran kambing setelah pengomposan terjadi karena proses penguraian bahan organik yang dilakukan oleh mikroorganisme menghasilkan amoniak dan nitrogen, sehingga $\mathrm{N}$ yang bereaksi dengan air akan membentuk NO3- dan $\mathrm{H}+$.

Rendahnya kandungan $\mathrm{P}$ pada POC disebabkan karena bahan organik tidak sepenuhnya dirombak menjadi unsur hara melainkan digunakan juga untuk proses metabolisme hidupnya. Fitris dkk, (2008) menambahkan bahwa dalam penelitiannya terjadi penurunan kandungan unsur hara pada pupuknya akibat aktivitas mikroorganisme dimana selain merombak phospor dan kalium juga menggunakannya untuk aktivitas hidupnya. Selain itu, juga bisa disebabkan karena mikroba pengurai telah mencapai fase statis (Fase Kematian) sebelum variabel ditentukan jika proses fermentasi diteruskan maka hasil yang didapatkan akan lebih sedikit dari sebelumnya (Santi, 2010). Menurut Amanillah (2001), dalam Adhis, dkk (2017) menyatakan peningkatan kadar P diduga dampak dari aktivitas Lactobacillus sp. yang mengubah glukosa menjadi asam laktat, sehingga lingkungan menjadi asam yang mengakibatkan $\mathrm{P}$ akan larut dalam asam organik yang dihasilkan mikroorganisme tersebut. Menurut Amanillah (2001), unsur K merupakan senyawa yang dihasilkan oleh metabolisme bakteri. Bakteri menggunakan ion-ion $\mathrm{K}+$ yang bebas pada bahan substrat sebagai katalisator, sehingga $\mathrm{K}$ akan meningkat seiring dengan semakin berkembangnya jumlah bakteri.

\section{KESIMPULAN}

Secara umum tingkat keterampilan peternak tentang pembuatan pupuk organik cair dari feses kambing pada kategori terampil. Prosedur pembuatan pupuk organik cair meliputi tahap persiapan, tahap pencampuran, dan tahap pengakhiran. Pada tahap persiapan sejumlah 13 orang atau 52\% peternak dengan kategori terampil, pada tahap pencampuran sejumlah 15 orang atau $60 \%$ peternak dengan kategori cukup terampil, dan pada tahap pengakhiran sejumlah 21 orang atau $84 \%$ peternak pada kategori sangat terampil. Kualitas fisik POC yang dihasilkan oleh peternak yaitu tidak berbau, warna kehitaman, kepekatan encer dan tekstur kasar. Kualitas kandungan unsur hara POC masih belum sesuai standar Permentan nomor 70 tahun 2011.

\section{V.SARAN}

Agar dilakukan penyuluhan dan pendampingan lebih lanjut sehingga peternak dapat menghasilkan kualitas pupuk organik cair yang sesuai dengan standar.

\section{DAFTAR PUSTAKA}

Ade , dkk., 2015. Pengaruh Pupuk Organik Padat Dan Cair Terhadap Pertumbuhan Dan Produksi Tanaman Seledri (Apium graveolens L.) Di Polybag. ISSN. 2085-9600. Fakultas Pertanian Universitas Muhamadiyah Palembang.

Adhis, dkk., 2017. Aplikasi Pupuk Organik Cair (POC) Kotoran Kambing Difermentasikan Dengan EM4 Terhadap Pertumbuhan Dan Produktivitas Tanaman Cabai Rawit (Capsicum Frustecents L.) Var Bara. Vol. 6 (3) Hlm : 182-187. Fakultas MIPA, Universitas Tanjungpura.

Amanillah, Z, 2001, Pengaruh Konsentrasi EM4 pada Fermentasi Urin Sapi Terhadap Konsentrasi N, P dan K, Skripsi, Fakultas Matematika dan Ilmu Pengetahuan Alam, Universitas Brawijaya, Malang.

Anonymous, 2017. Petunjuk Teknis Karya Ilmiah Penugasan Akhir. Sekolah Tinggi Penyuluhan Pertanian. 
Arifin, Z. 2016. Evaluasi Pembelajaran. Bandung: PT. Remaja Posdakarya.

Arikunto, S. 2013. Prosedur Penelitian: Suatu Pendekatan Praktik. Jakarta. Rineka Cipta.

Budya, dkk., 2014. Pengaruh Tiga Jenis Pupuk Kotoran Ternak (Sapi,Ayam,dan Kambing) Terhadap Pertumbuhan dan produksi Rumput Brachiaria Humidicola. ISSN : 2301-7783 Vol. 3 No. 2 Hlm : 5-9.

Dian, dkk., 2015. Pemanfaatan Limbah Ternak Kambing Etawa Sebagai Bahan Pupuk Organik Cair Untuk Budi Daya Baby Corn. Vol. 4 No. 2 Hlm : 143-149. Fakultas Matematika dan Ilmu Pengetahuan Alam. Universitas Negeri Surabaya.

Elmi, dkk., 2012. Pembuatan Pupuk Organik Cair Menggunakan Biosca dan EM4. ISSN. 1907-0500. Fakultas Teknologi Industri. Universitas Bung Hatta.

Hidayanti, YA, Kurnani, A, Marlina, ET, \& Harlia, E, 2011, Kualitas Pupuk Cair Hasil Pengolahan Fases Sapi Potong Menggunakan Saccharomyces cereviceae, Jurnal Ilmu Ternak vol. 11, no. 2, hal. 104-107.

Ida. 2013. Manfaat Penggunaan Pupuk Organik Untuk Kesuburan Tanah. Vol. $1 \mathrm{Hlm}$ : 30-42. Fakultas Pertanian. Universitas Tulungung.

Indah, KT, 2006, Pengaruh Waktu Aplikasi Pupuk Kandang Ayam dan Konsentrasi Pupuk Organik Cair Terhadap Pertumbuhan dan Produksi Tanaman Cabai Rawit (Capsicum frutescens Protobiont (2017) Vol. 6 (3) : 182 - 187.

Jumiati, E, 2009, Pengaruh Berbagai Konsentrasi EM4 Pada FermentasiPupuk Organik TerhadapPertumbuhan Dan Hasil Tanaman Bayam Merah (Amaranthus Tricolor L.) Secara Hidroponik. Program Studi agronomi, Skripsi (Jurnal) Fakultas Pertanian, Universitas Sebelas Maret, Surakarta.

Latifah, dkk. 2012. Pemanfaatan Sampah Organik Sebagai Bahan Pupuk Organik Cair Untuk Pertumbuhan Tanaman Bayam Merah (Alternanthera Fichoides). Lentera Bio, 1(3), 139-144.

Mardikanto, T., 2009. Sistem Penyuluhan Pertanian. Lembaga Pengembangan Pendidikan UNS dan UNS Press. Surakarta.

Maulana, YN, 2010, Kajian Penggunaan Pupuk Organik dan Jenis Pupuk N Terhadap Kadar N Tanah, Serapan N dan Hasil Tanaman Sawi (Brassica juncea L.) pada Tanah Litosol Gemolong, Skripsi, Jurusan Ilmu Tanah Fakultas Pertanian Universitas Negeri Sebelas Maret.

Muslihat, 2014, Pengaruh Pupuk Kotoran Kambing Terhadap Pertumbuhan dan Hasil Tanaman Terung, Skripsi, Fakultas Pertanian, Universitas Tanjungpura, Pontianak.

Pakpahan, H. T. 2017. Penyuluhan Pertanian. Plantaxia. Yogyakarta.

Rahmah, NL, Anggarini, S,. Pulungan, MH,. Hidayat N, \& Wignyanto, 2014, Pembuatan Kompos Limbah Log Jamur Tiram:Kajian Konsentrasi Kotoran Kambing Dan EM4 SertaWaktu Pembalikan, Jurnal Teknologi Pertanian, vol. 15 no. 1 hal. 5966. 
Ganang Trisno Priyambodo, dkk., Keterampilan Peternak Tentang Pembuatan Pupuk Organik Cair.

Setiana, L. 2005. Teknik Penyuluhan Dan Pemberdayaan Masyarakat. Ghalia Indonesia. Bogor.

Subhan, N, Nurtika \& Gunadi, N 2009, Respons Tanaman Tomat Terhadap Penggunaan Pupuk Majemuk NPK 15-15-15 Pada Tanah Latosol Pada Musim Kemarau, J. Hort., vol. 19, no. 1, hlm. 40-8. 